ROCZNIKI TEOLOGICZNE

Tom LXVI, zeszyt 5 - 2019

DOI: http://dx.doi.org/10.18290/rt.2019.66.5-7

KS. MAREK CHMIELEWSKI

\title{
TEOLOGIA DUCHOWOŚCI JAKO DYSCYPLINA NAUKOWA ZARYS PROBLEMATYKI
}

\author{
SPIRITUAL THEOLOGY AS A SCIENTIFIC DISCIPLINE \\ AN OUTLINE OF ISSUES
}

\begin{abstract}
Among the specialties offered by theological faculties at universities and colleges, there is often theology of spirituality. This means that it is a full-fledged scientific discipline. Therefore, it has its own history, own name that identifies it, the subject of research, specific sources and an adequate research method. At the university level, it is practiced by a large number of scientists whose achievements are recognized and appreciated in the world of science. In addition to university structures in which research and teaching are conducted, and conferences are convened, spiritual theologians form organizations and associations that have legal personality.

The article aims at to deeping aforementioned issues, taking polish theological and ecclesiastical background on board.

The awareness of the main methodological matters is very important for every committed theologian and his reliable scientific work, as well his spiritually-ecclesiastical vocation.
\end{abstract}

Key words: spirituality; theology; methodology; science; theological method; polish theological environment.

Wśród specjalizacji, jakie oferują wydziały teologiczne na wyższych uczelniach, w tym także na uniwersytetach, nierzadko znajduje się teologia duchowości. Oznacza to, że jest ona pełnoprawną dyscypliną naukową. Ma bowiem swoją historię, własną nazwę, która ją identyfikuje, przedmiot badań, specyficzne źródła i odpowiednią do tego metodę badawczą. Na poziomie uniwersyteckim uprawia ją dość liczne grono naukowców, których dorobek jest uznany i doceniany w świecie nauki. Oprócz struktur akademickich,

Ks. prof. dr hab. MAREK ChMIELEWSKI - kierownik Katedry Duchowości Systematycznej i Praktycznej na Wydziale Teologii KUL; wiceprezes Polskiego Stowarzyszenia Teologów Duchowości; przewodniczący Polskiego Towarzystwa Mariologicznego; adres do korespondencji: Al. Racławickie 14, 20-950 Lublin; e-mail: cechaem@kul.pl 
w ramach których prowadzone są badania i dydaktyka, a także zwoływane są konferencje naukowe, teologowie duchowości tworzą własne organizacje i stowarzyszenia, które mają osobowość prawną.

Mówimy tu głównie o teologii duchowości katolickiej, choć na podobnych zasadach może także funkcjonować teologia duchowości niekatolickiej, na przykład prawosławna czy protestancka.

Szczegółowe omówienie poszczególnych elementów uzasadniających naukowy status teologii duchowości wymagałoby obszernego studium z zakresu metodologii ${ }^{1}$. W niniejszym opracowaniu ograniczymy się więc do zarysu najważniejszych kwestii, uwzględniając przede wszystkim kontekst polski.

\section{ZARYS HISTORII TEOLOGII DUCHOWOŚCI}

Jeden z hiszpańskich autorów przedsoborowych Eulogio de la Virgen del Carmel przedstawił bogatą historię teologicznej refleksji nad życiem duchowym, porównując ją do faz rozwoju człowieka². Prehistoria teologii duchowości sięga samych początków chrześcijaństwa, kiedy teologia jako nauka formalnie jeszcze nie istniała. Najstarsze bowiem pisma autorów starochrześcijańskich oraz wiele dzieł Ojców Kościoła podejmuje zagadnienia właściwe dla obszaru współczesnej naukowej teologii duchowości. Znamienne jest to, że w czasach prześladowań Kościoła, oprócz traktatów apologetycznych, pisano także o modlitwie i potrzebie ascezy, jakby dla wykazania, że siłą chrześcijaństwa jest oparte na nich życie duchowe.

Wraz z tworzeniem się pierwszych form życia monastycznego stopniowo zaczęła krystalizować się teologiczna refleksja nad praktyką ewangelicznych rad czystości, ubóstwa i posłuszeństwa. Do klasyków w tym względzie należą w Kościele zachodnim m.in. św. Ambroży (†397), św. Hieronim († 420), Jan Kasjan († 435), św. Benedykt († 543), św. Izydor z Sewilli (†636) i inni. $\mathrm{W}$ tym czasie pod wpływem neoplatonizmu zaczęto interesować się doświadczeniem mistycznym, czego przykładem są pisma św. Grzegorza z Nyssy $(† 395)$, Ewagriusza z Pontu († 399) i Pseudo-Dionizego Areopagity ( $†$ ok. 500). Ich myśl na całe wieki ukierunkowała sposób uprawiania mistologii (teologii mistyki). Ten okres Eulogio de la Virgen del Carmel nazwa „dzieciństwem”

\footnotetext{
${ }^{1}$ Kwestie te bardziej szczegółowo przedstawiłem w książce pt. Metodologiczne problemy posoborowej teologii duchowości katolickiej, Lublin 1999.

${ }^{2}$ Proceso histórico de la formación de la teología espiritual como ciencia, „Teología Espiritual" 4(1960), s. 483-485.
} 
teologii duchowości, które obejmuje okres od starożytności aż do czasów scholastyki (XII-XIV w.), kiedy w wyniku systematyzacji całości wiedzy teologicznej krystalizowały się jej podstawowe pojęcia. W tym czasie problematyka teologicznoduchowa, podobnie jak w przypadku innych dyscyplin, uprawiana była w ramach jednej teologii. Nie miała więc jeszcze swej odrębności, którą stopniowo osiągała w następnych trzech wiekach, określanych przez naszego autora jako jej „młodość”. Duże znaczenie dla rozwoju teologicznej refleksji nad życiem duchowym w tym okresie miały pisma św. Bonawentury (†1274), mistyków nadreńskich: Mistrza Eckharta (†1337), bł. Jana Taulera $(\dagger 1361)$, bł. Henryka Suzo $(\dagger 1366)$, bł. Jana Ruysbroecka $(† 1381)$, Jana Gersona ( $†$ 1429), Dionizego Kartuza $(\dagger 1471)$ i innych.

„Dojrzałość” teologicznej refleksji nad życiem duchowym, przypadająca na wiek XVII, oznaczała całkowite wyodrębnienie się tej dyscypliny, skupionej wówczas na ascezie i mistyce. Świadczy o tym ilość i wysoka merytoryczna jakość pism powstałych w tym czasie takich autorów, jak: García Jimenez de Cisneros $(\dagger 1510)$, św. Ignacy z Loyoli $(\dagger 1556)$, św. Teresa od Jezusa $(\dagger 1582)$ i św. Jan od Krzyża $(† 1591)$, Ludwik z Granady († 1588), Franciszek z Osuny $(\dagger 1540)$ i św. Franciszek Salezy (†1622). Nie można też pominąć znaczącego wkładu polskich teologów „złotego okresu”, a wśród nich: Kaspra Drużbickiego SJ († 1662), Mikołaja z Mościsk OP († 1632), Tomasza Młodzianowskiego SJ († 1686) i Hieronima od św. Jacka - Andrzeja Cyrusa OCD $(\dagger 1647)$ oraz innych.

Na szczególną uwagę zasługuje Stefan Chryzostom Dobrosielski (†1676), krakowski franciszkanin, który w dziele Summarium asceticae et mysticae theologiae... (Kraków 1655) jako pierwszy dokonał rozróżnienia na teologię ascetyczną i mistyczną. Podział ten sto lat później utrwalił włoski jezuita Giovanni Battista Scaramelli (†1752) w dwóch osobnych traktatach wydanych pośmiertnie: Direttorio ascetico (Neapol 1752) i Direttorio mistico (Wenecja 1754). Po prawie dwustuletnim zastoju teologii, który szczególnie dotknął teologię duchowości, głównie na skutek potępienia jansenizmu i kwietyzmu, jej odrodzenie dokonało się pod koniec XIX wieku. Wiązało się to z silnym ruchem odnowy biblijno-patrystyczno-liturgicznej, której sprzyjała zalecana przez Kościół neoscholastyka. Impulsem do odrodzenia teologii duchowości było wydanie przez Leona XIII w 1897 roku encykliki o Duchu Świętym Divinum illud munus ${ }^{3}$.

${ }^{3}$ Zob. A. Huerga, La encíclica de León XIII sobre el Espíritu Santo, „Teología Espiritual” 26(1982), s. 72-83; R. ZAS FrIz DE COL, Dall'ascetica e mistica alla vita cristiana. Novant'anni dopo, ,Mysterion” 12(2019), nr 1, s. 27-42. 
Zaowocowało to dynamicznym „ruchem mistycznym” w pierwszych trzech dekadach XX wieku, który charakteryzował się wzmożonym zainteresowaniem problematyką teologicznoduchową, zwłaszcza mistyczną, co przyniosło rozkwit odnośnej literatury. Sprzyjały temu zwoływane wówczas kongresy teologiczne z okazji pięćsetlecia urodzin św. Teresy z Avila (1915) i czterechsetlecia jej kanonizacji (1922), a także trzystulecia kanonizacji św. Jana od Krzyża (1926), przy okazji której został ogłoszony Doktorem Kościoła.

„Ruch mistyczny” zapoczątkowała polemika pomiędzy dwoma francuskimi teologami ks. Augustem Saudreau ( $\uparrow 1946)$ i jezuitą Augustem Poulain († 1919) odnośnie do natury mistyki. W dyskusję włączyli się hiszpańscy autorzy: Juán-Gonzales Arintero OP († 1928) i Jerónimo Seisdedos SJ († 1923), a następnie teologowie ze środowiska rzymskiego, związani z uniwersytetami „Angelicum” i „Gregorianum”: dominikanin Reginald Garrigou-Lagrange $(\dagger 1964)$, jezuita Joseph De Guibert $(\dagger 1942)$, benedyktyn Anzelm Stolz († 1942) i karmelita Gabriel od św. Marii Magdaleny († 1953). Różnica zdań pomiędzy tymi głównymi uczestnikami dyskusji dotyczyła szeregu kwestii związanych $\mathrm{z}$ rozumieniem istoty mistyki i jej związku z ascezą, kontemplacji, roli cnót wlanych i darów Ducha Świętego w życiu duchowym, zjawisk nadzwyczajnych, psychologicznych ujęć doświadczenia duchowego łącznie z mistycznym itp. Wielość podejmowanych wątków i poczynione uzgodnienia stanowisk pozwoliły na dokonanie syntez doktrynalnych w zakresie teologii duchowości. Nie tylko w jakimś stopniu przełamano pokwietystyczne uprzedzenia co do duchowości, zwłaszcza mistyki, ale wypracowano zręby metodologiczne, dzięki czemu teologia duchowości, dotychczas przez wieki uprawiana głównie w szkołach zakonnych, mogła triumfalnie wejść na katedry uniwersyteckie ${ }^{4}$.

Pierwszą w świecie uniwersytecką katedrę teologii ascetyczno-mistycznej powołano w 1917 roku na Papieskim Uniwersytecie św. Tomasza w Rzymie „Angelicum”, a w dwa lata później na Papieskim Uniwersytecie Gregoriańskim. Zasadniczym celem wprowadzenia tej nowej dyscypliny w struktury uniwersyteckie była duchowa formacja kleru, o którą zabiegali ówcześni papieże począwszy od św. Piusa $X^{5}$.

Dostrzeżenie duchowości jako pełnoprawnej dyscypliny teologicznej w oficjalnych dokumentach Kościoła przyczyniło się w następnych dziesięciole-

\footnotetext{
${ }^{4}$ Zob. C. GARcía, Corrientes nuevas de teología espiritual, Madrid 1971, s. 19-21; J.-M. GARCíA, Teología espiritual. Elementos para una definición de su estatuto epistemologico, Roma 1995, s. 57175; F. Asti, Spiritualità e mistica. Questioni metodologiche, Città del Vaticano 2003, s. 17-63.

${ }^{5}$ Szerzej na ten temat zob. M. CHMIELEWSKI, Teologia duchowości w wybranych dokumentach Kościoła, „Roczniki Teologiczne” 47(2000), z. 5, s. 93-101.
} 
ciach do powstawania kolejnych katedr i ośrodków uniwersyteckich w tym zakresie. W 1960 roku na Papieskim Wydziale Teologicznym „Teresianum” powołano instytut duchowości. Dziesięć lat później podobny instytut utworzyli franciszkanie na „Antonianum”, a następnie w 1973 roku salezjanie na swoim Uniwersytecie Papieskim w Rzymie. Także w Polsce, dokładnie czterdzieści lat od wprowadzenia teologii duchowości w struktury uniwersyteckie, w 1957 roku na KUL staraniem ks. Antoniego Słomkowskiego $(† 1980)$ utworzono Katedrę Teologii Ascetyczno-Mistycznej6.

Z uwagi na różnorodność form organizacyjnych obecnie istniejących 289 samodzielnych kościelnych wydziałów teologicznych i wydziałów teologicznych, działających na 1365 uniwersytetach katolickich, jakie są na świecie ${ }^{7}$, jest praktycznie niemożliwe podać nawet przybliżoną liczbę katedr czy podobnych do nich ośrodków badawczych zajmujących się teologią duchowości w sposób naukowy. Dodatkowo sprawę komplikuje zróżnicowanie w nazewnictwie tych placówek, choć obecnie dominuje nazwa „duchowość" lub „teologia duchowości”. Niemniej jednak „zadomowienie się” teologii duchowości w strukturach akademickich dostatecznie świadczy, że jest ona pełnoprawną dyscypliną naukową. Potwierdza to przede wszystkim jej metodologiczna fizjonomia, którą wyraża jej adekwatna nazwa, własny przedmiot badań i źródła oraz odpowiednia do tego metoda badawcza.

\section{NAZWA DYSCYPLINY}

Nazwa interesującej nas dyscypliny ewoluowała i zmieniała się, zataczając swoisty historyczny krąg. Obecnie powszechnie stosuje się określenie „duchowość" lub „teologia duchowości”. Po raz pierwszy w literaturze chrześcijańskiej pojęcie to pojawiło się w latach dwudziestych V wieku w listach Pelagiusza, który zachęcał dorosłego neofitę imieniem Thesiphont słowami: Age, ut in spiritualitate proficias. Tak więc obok określeń: „asceza” i „mistyka”, „duchowość” należy do najstarszego słownika teologicznego. Pierwotnie oznaczało ono dążenie do chrześcijańskiej doskonałości i było obarczone manichejskim dualizmem, gdyż łacińskiemu spiritualitas przez całe wczesne średniowiecze przeciwstawiano carnalitas (cielesność), a w niektó-

\footnotetext{
${ }^{6}$ Zob. M. ChMIELEwski, Ks. Antoni Stomkowski prekursor akademickiej teologii duchowości w Polsce (1957-2007), w: Lectio divina (Homo meditans, t. 29), red. J.M. Popławski, Lublin 2008, s. 161-179.

7 Zob. https://www.lastampa.it/vatican-insider-it/2018/01/29/news/istituti-ecclesiastici-nel-mon do-sono-circa-800-con-64mila-studenti-1.33973540?refresh_ce [30.10.2019].
} 
rych przypadkach nawet animalitas (zwierzęcość). W dobie scholastyki pojęcie spiritualitas oznaczało niematerialność duszy ludzkiej, dlatego najwybitniejsi scholastycy, jak św. Tomasz z Akwinu czy św. Bonawentura, praktycznie go nie używali w swoich tekstach duchowych.

Stopniowe zacieranie pierwotnego sensu tego pojęcia sprawiło, że zanikło ono w okresie rozkwitu teologii duchowości w XVII i XVIII wieku, ustępując miejsca określeniu „teologia ascetyczno-mistyczna” czy „teologia mistyczna”. Po potępieniu kwietyzmu, teologowie zajmujący się teologią ascetyczno-mistyczną, czyli de facto duchowością, być może nie chcąc narazić się na oskarżenie o sprzyjanie tendencjom kwietystycznym, odeszli od dotychczasowej nazwy na rzecz określeń „teologia doskonałości” i „teologia życia wewnętrznego", które były w użyciu przynajmniej do czasu Soboru Watykańskiego II. Jednak dotychczasowe nazwy: „ascetyka” i „mistyka”, „życie wewnętrze” i „teologia życia wewnętrznego”, a tym bardziej „doskonałość" i „teologia doskonałości” nie wyczerpywały szerokiego wachlarza zagadnień związanych $\mathrm{z}$ doświadczeniem zjednoczenia $\mathrm{z}$ Bogiem i uświęceniem, ujmując tę rzeczywistość w sposób jedynie aspektowy. $\mathrm{Z}$ tej racji w okresie wspomnianego „ruchu mistycznego” szczęśliwie powrócono do starożytnej nazwy „duchowość”. Stało się to najpierw w dziełach A. Saudreau pt. Manuel de spiritualité (Paryż 1920) i Pierre Pourrata pt. La spiritualité chretienne (Paryż 1918-1928), następnie w tytule czasopisma „La Vie Spirituelle", a wreszcie w monumentalnym dziele pt. Dictionnaire de spiritualité ascetique at mystique (Paryż 1932-1995). Pojęciu „duchowość” przywrócono pierwotny sens i od tamtej pory rozumie się przez nie egzystencjalną odpowiedź na całość chrześcijańskiego doświadczenia religijnego, czyli życie duchowe. Nierzadko tym mianem określa się także teologiczną refleksję naukową nad tym doświadczeniem, czyli teologię duchowości ${ }^{8}$.

Warto jeszcze wspomnieć, że oprócz wymienionych wyżej określeń, na przestrzeni dwutysiącletniej historii chrześcijańskiej refleksji teologicznej pojawiało się wiele nazw i tytułów dzieł, służących na określenie interesującej nas dyscypliny teologicznej i jej przedmiotu, jak na przykład: abecedarium spirituale, doctrina spirituale, mistagogia, theologia affectiva, theologia cordis, theologia medica, praxis spiritualis, scientia sanctorum i innych?

${ }^{8}$ Zob. T. Alvarez, Experiencia cristiana y Teologia Espiritual, „Seminarium” 26(1974), s. $94-$ 109; A. Queralt, La «Espiritualidad» como disciplina teológica, „Gregorianum” 60(1979), s. 330.

${ }^{9}$ Zob. D. LAsić, Theologia christiana perfectidica, „Antonianum” 42(1967), s. 192-194. 


\section{PRZEDMIOT BADAŃ}

Znalezienie adekwatnej nazwy dla danej dyscypliny naukowej służy przede wszystkim wskazaniu na przedmiot jej badań, zarówno materialny (czyli, co jest badane?), jak i formalny (czyli pod jakim kątem, a jakim aspekcie jest badane?). W ogólnej metodologii nauki przedmiot materialny stanowi czynnik pozwalający wyróżnić daną dziedzinę badań, zaś sposób ujęcia go, czyli tzw. przedmiot formalny, stanowi podstawę specyfikacji dyscyplin w ramach danej dziedziny.

Jeśli chodzi o dziedzinę nauk teologicznych, to wspólnym ich przedmiotem materialnym jest szeroko rozumiana uświęcająco-zbawcza relacja Bógczłowiek w całym jej egzystencjalnym kontekście, ujmowanym przez pryzmat tego, co zawarte jest w Bożym Objawieniu i czego naucza Kościół. Pomocne $\mathrm{w}$ tym zakresie są nauki biblijne, patrystyka $\mathrm{z}$ patrologią oraz historia Kościoła. Każda z dyscyplin teologicznych podchodzi do tego wspólnego przedmiotu materialnego na sposób sobie właściwy. Upraszając nieco, można więc powiedzieć, że teologia systematyczna bada go głównie od strony przedmiotowości wiary. A zatem teologia fundamentalna uzasadnia obiektywność i powszechność tej relacji; dogmatyka relację Bóg-człowiek bada od strony poznawczo-obiektywnej, dociekając i wyjaśniając, kim jest Bóg w swej Nieskończoności i kim jest człowiek w swojej skończoności ukierunkowanej ku wieczności; teologia moralna zaś na tę samą relację patrzy z punktu widzenia powinności moralnych. Teologia pastoralna, czasem nazywana także teologią praktyczną, ze wszystkimi swoimi specjalizacjami (liturgiką, homiletyką, katechetyką itd.) do fundamentalnej dla wiary chrześcijańskiej relacji Bóg-człowiek podchodzi od strony praktycznej, mając na względzie jej funkcję eklezjalną i wspólnototwórczą ${ }^{10}$.

Natomiast teologia duchowości tę samą rzeczywistość zbawczej inicjatywy Boga, działającego w Kościele przez Jezusa Chrystusa w mocy Ducha Świętego, opisuje i bada od strony podmiotowej. Jej przedmiotem formalnym jest zatem to wszystko, co dzieje się w człowieku wówczas, gdy zawiązuje się i rozwija uświęcająco-zbawcza więź z Bogiem. Innymi słowy, przedmiotem formalnym teologii duchowości jest doświadczenie duchowe, którego szczególną postacią jest doświadczenie mistyczne ${ }^{11}$.

\footnotetext{
${ }^{10}$ Zob. R. ZAS FRIZ DE COL, La teologia spirituale e la ricerca della triplice unità: disciplinare, intradisciplinare e interdisciplinare, „Mysterion” 6(2013), nr 1, s. 65-85.

${ }^{11}$ Zob. A. GRILlo, Il dono e la mistica: una svolta ,teologica” della fenomenologia?, w: Esperienza mistica e pensiero filosofico. Atti del Colloquio „Filosofia e mistica”, red. F. Miano, G. de Simone, Città del Vaticano 2003, s. 26-43; F. Asti, Spiritualità e mistica. Questioni
} 
Odnośnie do tego zgodni są niemal wszyscy współcześni teologowie duchowości, którzy w swoich publikacjach podejmują kwestie metodologiczne. Hans Urs von Balthasar $(† 1988)$ i Gustave Thils $(\dagger 2000)$ podkreślają przy tym, że chrześcijańska duchowość, zakorzeniona w doświadczeniu duchowym, jest funkcją świętości, która jest fundamentalnym powołaniem chrześcijańskim ${ }^{12}$. Autorytet $\mathrm{w}$ zakresie teologii duchowości - jezuita Charles Andrè Bernard (†2001), wskazuje na chrześcijańskie doświadczenie duchowe jako specyficzny przedmiot teologii duchowości ${ }^{13}$. W podobnym tonie wypowiada się Innocenzio Colosio ( $†$ 1997), który w doświadczeniu duchowym mocno podkreślał wymiar chrystologiczny i pneumatologiczny ${ }^{14}$. Z kolei franciszkanin Atanasio G. Matanić przez duchowość jako dyscyplinę teologiczną rozumie wiedzę o życiu duchowym, które rozważane jest zarówno w jego wymiarze teologicznym, jak i fenomenologicznym ${ }^{15}$. Na gruncie polskim już w latach siedemdziesiątych XX wieku koncepcję teologii duchowości, jako teologii doświadczenia duchowego, rozwijał ks. Walerian Słom$\mathrm{ka}$, inspirując tą myślą lubelskie środowisko teologów duchowości ${ }^{16}$.

Współczesne nurty określane jako „nowa duchowość” stanowią potężne wyzwanie dla katolickiej teologii duchowości, która - ujmując rzecz od strony metodologicznej - musi zachować daleko posuniętą ostrożność w odwoływaniu się do doświadczenia duchowego ${ }^{17}$. Zarówno bowiem samo pojęcie „doświadczenia duchowego”, łącznie z „doświadczeniem mistycznym”, jak i ich desygnaty, cieszą się dużą popularnością i zainteresowaniem, co powoduje, że ta rzeczywistość postrzegana jest w sposób wieloznaczny. Tym

metodologiche, s. 101-139; A.G. MATANIĆ, L'esperienza spirituale come fonte conoscitiva in spiritualità, w: Esperienza e spiritualità, red. Ch.A. Bernard, Roma 2005, s. 243-255.

12 G. Thils, Saintetè chrètienne, Thielt 1958, s. 27-29; H. URS VON BALTHASAR, Spiritualità, „Theologisches Jahrbuch” 5(1961), s. 170-178.

13 „La teologia spirituale è una disciplina teologica che, fondata sui principi della rivelazione, studia l'esperienza spirituale cristiana, ne descrive lo sviluppo progresivo e ne fa conoscere le strutture e le leggi". Ch.A. BERnARD, Teologia spirituale, Milano 1987, s. 70.

${ }^{14}$ Zob. I. Colosio, Tentativo di una nuova definizione della teologia spirituale, „Rivista di Ascetica e Mistica" 21(1976), s. 298-301.

${ }^{15}$ La spiritualità come scienza. Introduzione metodologica allo studio della vita spirituale Cristiana, Cinisello Balsamo 1990, s. 42.

${ }^{16}$ Doświadczenie chrześcijańskie $i$ jego rola $w$ poznaniu Boga. Studium $w$ świetle fenomenologicznej metody Husserla, Lublin 1972; przedruk w: Bóg jest Miłością. Księga jubileuszowa ku czci Księdza Profesora Waleriana Słomki z okazji pięćdziesięciolecia święceń kapłańskich, red. M. Chmielewski, A. Rybicki, Lublin 2006, s. 65-220.

${ }^{17}$ Szerzej na ten temat zob. J. MARIAŃsKi, Nowa duchowość jako megatrend społeczno-kulturowy - mit czy rzeczywistość, „Uniwersyteckie Czasopismo Socjologiczne” 2015, nr 13, s. 22-45; M. ChMielewski, Duchowość chrześcijańska na tle współczesnych koncepcji duchowości. Zarys problematyki, „Roczniki Teologiczne” 64(2017), z. 5, s. 159-179. 
bardziej więc potrzeba odpowiedniej metody badawczej, która pozwoli nie tylko właściwie rozpoznawać źródła „doświadczeniowe”, ale także obiektywizować wyniki swoich badań i zweryfikować je w świetle Objawienia oraz Magisterium Ecclesiae, co stanowi specificum uprawiania teologii jako takiej.

\section{4. ŹRÓDEA TEOLOGII DUCHOWOŚCI}

Kwestia źródeł poznania naukowego, zwana topiką, to jeden z ważnych elementów szczegółowej metodologii nauk. Jednak w dotychczasowych studiach metodologicznych odnośnie do teologii duchowości była ona traktowana marginalnie. Autorzy, którzy podejmują tę kwestię, na ogół zakładają, że duchowość - ponieważ należy do dziedziny nauk teologicznych posługuje się tymi samymi źródłami co inne dyscypliny teologiczne. Nie uwzględniają więc jej specyfiki ${ }^{18}$. Tymczasem omówiony przedmiot formalny teologii duchowości, jakim jest doświadczenie duchowe, domaga się wskazania takich źródeł, dzięki którym będzie ono poznawczo dostępne ${ }^{19}$.

Prowadząc własne badania $\mathrm{w}$ tym zakresie, autor niniejszego opracowania proponuje zatem, aby oprócz źródeł wspólnych, którymi są: Pismo Święte, pisma Ojców Kościoła, Magisterium Ecclesiae i cała bogata tradycja teologiczna, zwrócić szczególną uwagę na specyficzne dla teologii duchowości źródła „doświadczeniowe”. Ze względu na ich transparentność dla doświadczenia duchowego, można je podzielić na niesformalizowane, a tym samym bezpośrednie, oraz sformalizowane, a przez to zapośredniczone. Oprócz tego teologia duchowości korzysta ze źródeł pomocniczych, jakimi są nauki humanistyczne.

Z punktu widzenia epistemologicznego, największą wartość dla badań teologicznoduchowych mają te źródła, które zawierają bezpośrednie informacje ze strony podmiotu o jego doświadczeniu duchowym. Na ogół nie mają one określonych form o charakterze naukotwórczym, dlatego można je nazwać niesformalizowanymi. Zwykle są to różnego rodzaju zapiski, notatki duchowe, pamiętniki czy epistolografia poszczególnych osób, zawierające duży ładunek faktograficzny, ale nie pozbawione czasem jakiegoś elementu

${ }^{18}$ A. GUERRA, Teología espiritual una ciencia no identificada. „Revista de Espiritualidad” 39 (1980), s. 344; M. BELDA, Lo statuto epistemologico della teologia spirituale nei manuali recenti (1978-1989), „Annales theologici” 6(1992), s. 454-457.

${ }^{19}$ Zob. G. MoIoli, Dimensione esperienziale della spiritualità, w: Spiritualità. Fisionomia e compiti, red. B. Calati, B. Secondin, T.P. Zecca. Roma 1981 s. 53-54; Ch.A. BERNARD. Introduzione alla teologia spirituale, Casale Monferrato 1994, s. 11-13. 
doktrynalnego, zwłaszcza wtedy, gdy podmiot ma odpowiednią formację intelektualno-teologiczną albo jego przeżycie duchowe (np. chrystofania lub mariofania) ma charakter profetyczny.

Innego rodzaju specyficznym źródłem dla badań teologicznoduchowych są dające się zweryfikować różne studia, analizy, twierdzenia, poglądy, relacje czy opisy, które dotyczą wspomnianego wyżej indywidualnego doświadczenia duchowego. Są to więc tzw. źródła zapośredniczone i zarazem sformalizowane, gdyż z uwagi na zastosowanie jakiejś formy jego ujęcia nie dają weń bezpośredniego wglądu. Ze względu na sposób ujęcia jednostkowego doświadczenia duchowego, można je podzielić na źródła opisowo-komunikujące i analityczno-systematyczne. Mamy tu na myśli relacje osób trzecich odnośnie do doświadczeń duchowych badanego podmiotu, ich świadectwa, opracowania, a także analizy i pogłębione studia. Owszem, dają one wgląd w podmiotowe doświadczenie duchowe, jednak nie bezpośrednio, lecz aspektowo lub przez pryzmat założeń wstępnych badacza, co skądinąd może być bardzo pomocne dla dalszych studiów teologicznoduchowych ${ }^{20}$.

Każde z omówionych źródeł, specyficznych dla teologii duchowości, ma inną wartość poznawczą, zarówno w sensie formalnym, jak i merytorycznym. Rzadko też są one brane jako jedyne źródła w całym procesie naukotwórczym. Należy je zatem ujmować integralnie, gdyż zbytnie skoncentrowanie się na jednym rodzaju źródeł niesie ze sobą ryzyko redukcjonistycznego potraktowania wielowymiarowego doświadczenia duchowego.

W prowadzeniu badań teologicznoduchowych zachodzi niekiedy potrzeba sięgania do innych dyscyplin naukowych, zwłaszcza humanistycznych, takich jak: psychologia, pedagogika, nauki filologiczne, które są pomocne w analizach opisów mistycznych obfitujących w symbole i formy poetyckie, historia nieodłączna $\mathrm{w}$ badaniach związanych $\mathrm{z}$ hagiografią i biografistyką itp. Wszystkie one stanowią tzw. źródła pomocnicze ${ }^{21}$.

${ }^{20}$ Zob. M. ChMielewski, Las fuentes de la teología espiritual, w: Dar razón de la esperanza. Homenaje al prof. dr. José Luis Illanes, red. T. Trigo, Pamplona 2004, s. 843-855.

${ }^{21}$ Zob. F. ASTI, Approcci socio-psicologici per una rinnovata teologia spirituale, „Mysterion" 5(2012), nr 1, s. 25-44; J.M. GARCÍA, Lo statuto epistemologico della Teologia spirituale in contesto interdisciplinare, „Mysterion” 5(2012), nr 2, s. 48-75; G. CAVAZOS-GonZÁlEZ, Il metodo socio-spirituale per lo studio teologico dei classici spirituali cristiani, „Mysterion” 8(2015), nr 2, s. 206-216. 


\section{METODA BADAWCZA}

W sensie ogólnym metoda w nauce określa logiczny, oparty na źródłach i dający się zweryfikować ciąg różnych czynności naukotwórczych, które badacz ma podejmować, aby dotrzeć do prawdy o otaczającej go rzeczywistości. Metodę każdej nauki można rozpatrywać od strony formalnej, epistemologicznej i treściowej. Jeśli chodzi o formalną stronę metody, to dotyczy ona przede wszystkim tego, na jakich przesłankach się opiera oraz jakim językiem i pojęciami operuje. $Z$ kolei strona epistemologiczna dotyczy właściwych dla danego typu źródeł czynności wiedzotwórczych. Natomiast ujęcie metody od strony treściowej obejmuje sposób osiągania i prezentowania wniosków, jakie płyną z podjętych działań badawczych ${ }^{22}$.

Odnosząc to do teologii duchowości, należy stwierdzić, że stosowana w niej metoda od strony formalnej bazuje na personalizmie. Jej bowiem przedmiotem formalnym jest - jak wspomnieliśmy - doświadczenie osobowej relacji Boga i człowieka. Jest to relacja miłości, możliwa jedynie w świecie osób. Wszelkie więc badanie doświadczenia duchowego w innej perspektywie niż personalistyczna, czyli bez uwzględnienia ontologicznej i egzystencjalnej niepowtarzalności osoby, w samym punkcie wyjścia byłoby chybione ${ }^{23}$.

Charakterystyczną cechą personalizmu jest jego otwarcie na wszystko, co inspiruje i prowadzi do pełniejszego poznania oraz rozumienia osoby. Dopuszcza zatem wielość aspektów bytu i dróg poznania, jednak zawsze z zatroskaniem o zachowanie niezmiennego odniesienia osoby ludzkiej do Pełni Bytu Osobowego. Możliwe jest zatem zastosowanie w badaniach nad doświadczeniem duchowym metod właściwych fenomenologii jako sposobu odkrywania nieuwarunkowanej prawdy o osobie. Nie chodzi jednak o przyjęcie fenomenologii jako filozoficznego systemu równoprawnego z personalizmem, co groziłoby sprowadzeniem teologii duchowości do fenomenologii zjawisk duchowych czy jakiegoś rodzaju antropologii duchowej, lecz o sposób opisu oraz identyfikację doświadczenia duchowego bez przyjmowania założeń wstępnych. Fenomenologia bowiem jako „nauka początku” zaczyna badania od tego, co jest przed zajęciem jakiegokolwiek stanowiska, a więc od tego, co dane jest naocznie, a co można uchwycić bezpośrednio i przedrefleksyjnie. Takie zastosowanie elementów fenomenologii w badaniach

${ }^{22}$ Zob. C. GARCíA, Evolución del método de teología espiritual en las últimas décadas, „Mysterion" 12(2019), nr 1, s. 15-26.

${ }^{23}$ Zob. M. Soto GonZales, Sobre la antropologia hermeneutica como metodo, „Estudios” 36 (1980), s. 5-11; Cz.S. BARTNIK, Metodologia teologiczna, Lublin 1998, s. 99; TENŻE, Hermeneutyka personalistyczna, Lublin 1994, s. 92-95. 
nad doświadczeniem duchowym wynika z samego przedmiotu badań, który ujmowany jest bezpośrednio ${ }^{24}$.

Teologicznoduchowa metoda badawcza, rozpatrywana od strony treściowej, obejmuje trzy główne elementy: a) weryfikację fenomenologicznie opisanego doświadczenia duchowego w świetle Objawienia i nauczania Kościoła oraz kryteriów moralnych; b) obiektywizację uzyskanych danych poprzez skonfrontowanie ich z podobnym doświadczeniem duchowym innych osób, zwłaszcza tych, których świętość Kościół potwierdził aktem beatyfikacji lub kanonizacji, a także odniesienie ich do szeroko rozumianego duchowego dziedzictwa Kościoła; c) aktualizację, polegającą na wskazaniu praktycznych norm i wskazań dla życia duchowego ${ }^{25}$.

Wbrew zgłaszanym niekiedy obawom, współczesnej teologii duchowości, która bada przede wszystkim doświadczenie duchowe także przy zastosowaniu niektórych elementów oglądu fenomenologicznego, nie grozi popadnięcie w subiektywizm. Chroni ją przed tym weryfikacja i obiektywizacja wyników badań w świetle Objawienia oraz nauczania Kościoła. Natomiast posiłkowanie się elementami fenomenologii mocniej osadza ją w realności osoby ludzkiej i chroni przed popadnięciem w abstrakcjonizm i spirytualizm, typowy dla niektórych współczesnych ruchów, zwłaszcza sekt.

Należy jeszcze dodać, że z uwagi na teologiczny charakter omawianej tu dyscypliny naukowej, w zarysowanej metodzie badawczej znajduje zastosowanie tradycyjny - dedukcyjny sposób myślenia naukowego, w którym przesłanką większą są dane Objawienia i nauczanie Kościoła, zaś przesłanką mniejszą dane pochodzące $\mathrm{z}$ doświadczenia duchowego. Jednak bardziej specyficzny dla współczesnej teologii duchowości jest redukcyjny sposób myślenia, wychodzący od danych doświadczenia duchowo-religijnego i zmierzający ku zobiektywizowaniu ich w świetle Objawienia oraz nauczania Kościoła.

Jednym słowem, stosowaną we współczesnej teologii duchowości metodę można nazwać integralną metodą personalistyczną ${ }^{26}$.

${ }^{24}$ Zob. D.B. PERrin, Metodologia ermeneutica nella spiritualità cristiana: fenomenologia e interdisciplinarità, „Mysterion” 10(2017), nr 1, s. 5-21; L. PereIRA DE OliveIRA, Fenomenologia della Religione e Teologia Spirituale. Applicazione del Metodo di Juan de Dios Martin Velasco alla Teologia Spirituale, tamże, s. 36-43.

${ }^{25}$ Zob. R. ZAS FRIZ DE COL, Un metodo fenomenico-cognitivo per comprendere la vita cristiana e il suo sviluppo, „Mysterion” 6(2013), nr 2, s. 191-219; J.M. GARCía GuTIÉRREZ, Il metodo «teologico esperienziale» della teologia spirituale, „Mysterion” 9(2016), nr 1, s. 5-17.

${ }^{26}$ Jerzy Wiesław Gogola OCD, nawiązując do doktryny św. Teresy z Lisieux, mówi o metodzie empatyczno-sapiencjalnej w teologii duchowości. Zob. Metoda empatyczno-sapiencjalna w teologii duchowości, ,Itinera spiritualia” 1(2008), s. 21-34. 


\section{6. ŚRODOWISKO TEOLOGÓW DUCHOWOŚCI}

Ściśle naukowy charakter każdej dyscypliny znajduje uzasadnienie nie tylko w jej aspekcie przedmiotowym, na który składa się nazwa, przedmiot badań, źródła i metoda, ale także w aspekcie podmiotowym. Stanowią go konkretni naukowcy, którzy tworzą ośrodki akademickie dedykowane danej dyscyplinie, stowarzyszenia specjalistów oraz ich działalność w postaci publikacji i konferencji naukowych. Także pod tym względem teologia duchowości w Polsce legitymuje się dojrzałymi strukturami i bardzo bogatym dorobkiem ${ }^{27}$.

Jak wspomniano, pierwszym i największym w Polsce ośrodkiem uniwersyteckim, zajmującym się teologią duchowości, jest Instytut Teologii Duchowości na Katolickim Uniwersytecie Lubelskim Jana Pawła II, który od $1 \mathrm{X}$ 2019 roku, w związku z wprowadzeniem „konstytucji dla nauki”, ponownie został nazwany Sekcją Teologii Duchowości. Ma on swe początki w założonej w 1957 roku przez ks. A. Słomkowskiego katedrze teologii ascetyczno-mistycznej. Aktualnie jest w nim zatrudnionych 6 pełnoetatowych samodzielnych pracowników naukowych, w tym 3 profesorów tytularnych. W ciągu ponad 60 lat jego istnienia obroniono ponad 850 magisteriów, uzyskano około 135 doktoratów i przeprowadzono 10 przewodów habilitacyjnych ${ }^{28}$.

Chronologicznie drugi uniwersytecki ośrodek teologii duchowości powstał w 1990 roku na ówczesnej Akademii Teologii Katolickiej, przekształconej w 1999 roku w Uniwersytet Kardynała Stefana Wyszyńskiego. Obecnie w ramach Instytutu Teologii Systematycznej na Wydziale Teologicznym tegoż uniwersytetu funkcjonują dwie katedry: Teologii Życia Duchowego i Mistyki Chrześcijańskiej, w której zatrudnionych jest 4 pracowników naukowych.

$\mathrm{Na}$ Papieskim Uniwersytecie Jana Pawła II w Krakowie działa Instytut Teologii Duchowości, na który składają się dwie katedry: historii duchowości i teologii duchowości z obsadą 4 samodzielnych pracowników naukowych, w tym 3 profesorów tytularnych. Współpracuje z nim Karmelitański Instytut Duchowości w Krakowie założony w 1990 roku.

Podobne zakłady lub katedry, zajmujące się teologią duchowości, są na większości wydziałów teologicznych w Polsce, które wchodzą w skład uniwersytetów państwowych.

\footnotetext{
${ }^{27}$ Szerszą panoramę współczesnej polskiej teologii duchowości przedstawiłem w artykule pt. Wspótczesna polska teologia duchowości, „Duchowość w Polsce” 19-20(2017-2018), s. 191-217.

${ }^{28}$ Zob. M. ChMIELewSKi, Instytut Teologii Duchowości, w: 100 lat teologii na KUL, red. S. Nowosad, J. Mastej, Lublin 2018, s. 109-115.
} 
Duże znaczenie dla rozwoju polskiej teologii duchowości oraz integracji liczącego co najmniej kilkaset osób środowiska specjalistów w zakresie duchowości jest Polskie Stowarzyszenie Teologów Duchowości, które powstało w 2008 roku na bazie powołanej do istnienia w 1983 roku Sekcji Duchowości Teologów Polskich. Jego statutowym celem jest prowadzenie badań w dziedzinie duchowości, promowanie i popularyzowanie wiedzy w zakresie duchowości katolickiej, integrowanie środowiska teologów duchowości w Polsce i koordynowanie współpracy z formatorami duchowymi.

\section{POLSKA LITERATURA TEOLOGICZNODUCHOWA}

Innym podmiotowo-materialnym wymiarem duchowości jako dyscypliny naukowej są publikacje, nierzadko jako owoc różnych konferencji naukowych. Lista polskich publikacji tego rodzaju jest bardzo długa. Chodzi tu, oczywiście, przede wszystkim o systematyczno-teologiczne ujęcia rodzimego pochodzenia, nie zaś o wszystkie pozycje poświęcone tematyce życia duchowego, będące w znacznej mierze publikacjami o charakterze formacyjno-dewocyjnym i do tego tłumaczone z obcych języków.

O tym, że teologia duchowości w Polsce ma swe należne miejsce w palecie dyscyplin naukowych, uprawianych na uniwersytetach, świadczą najważniejsze pozycje książkowe i serie wydawnicze.

$\mathrm{Na}$ długo przed tym, zanim powstała pierwsza w Polsce katedra teologii ascetyczno-mistycznej, w Krakowie Józef Andrasz SJ († 1963) zainicjował serię pod nazwą „Biblioteka Życia Wewnętrznego”. Wydawana była w latach 1921-1950 przez Wydawnictwo Apostolstwa Modlitwy i zawierała najbardziej wartościowe dzieła takich autorów, jak: św. Jan od Krzyża, bł. Columban Marmion, Renè de Maugminy, Maurycy Meschler, Raoul Plus, August Saudreau, Adolphe Tanquerey i św. Franciszek Salezy. W sumie ukazały się 44 tomy $^{29}$.

W latach 1976-2015 na KUL organizowane były Tygodnie Duchowości, przekształcone w 2001 roku na Dni Duchowości. Ich pokłosiem była ciesząca się dużym uznaniem seria wydawnicza pt. „Homo meditans”, wydawana w latach 1984-2008, licząca 29 tomów, w których podejmowane były bazowe zagadnienia dotyczące życia duchowego, jak: modlitwa, kontemplacja, asceza, cnoty teologalne, duchowość eklezjalna i maryjna, duchowość

\footnotetext{
${ }^{29}$ Zob. M. ChMIELEwSKI, ,Biblioteka Życia Wewnętrznego”, w: Leksykon duchowości katolickiej, red. M. Chmielewski, Lublin-Kraków 2002, s. 82.
} 
św. Józefa i św. Jana Pawła II, angelologia i duchowość biblijna, a także zagrożenia współczesnej duchowości ${ }^{30}$.

Również w środowisku KUL w latach 2000-2008 ukazała się niewielka, ale wartościowa seria poświęcona szeroko rozumianej tematyce modlitwy pt. „Homo orans”, zawierająca 8 tomów.

Nawiązaniem do obydwu lubelskich serii jest zapoczątkowany w 2014 roku cykl publikacji pt. „Spiritualitas”, obejmujący dotychczas 4 tomy.

W warszawskim środowisku teologów duchowości, związanym z ATK, a obecnie z UKSW, w 1998 roku rozpoczęto wydawać serię pt. „Mistyka polska”, a rok później serię „Mistyka chrześcijańska”. W ramach obydwu serii ukazało się w sumie 151 tomów o bardzo zróżnicowanej tematyce.

Na Wydziale Teologicznym Uniwersytetu im. Adama Mickiewicza w Poznaniu od 2009 roku w formie reprintów publikuje się serię pt. „Pisarze ascetyczno-mistyczni Polski”, w ramach której dotychczas ukazały się 4 tomy.

Karmelitański Instytut Duchowości w 2008 roku, wśród wielu publikacji, zainicjował rocznik naukowy pt. „Itinera spiritualia”, koncentrujący się głównie wokół duchowości karmelitańskiej. Dotychczas ukazało się 12 tomów.

W ramach działalności Sekcji Duchowości Teologów Polskich w latach 1993-2004 wydano 10 tomów z serii „Duchowość w Polsce”. Od chwili przekształcenia Sekcji w Polskie Stowarzyszenie Teologów Duchowości ten tytuł przejął wydawany od 2009 roku rocznik naukowy. Ponadto środowisko to opracowało i wydało pierwszy w Polsce Leksykon duchowości katolickiej (red. M. Chmielewski, Lublin-Kraków 2002), który cieszył się dużym zainteresowaniem zarówno wśród badaczy, jak i formatorów.

$\mathrm{W}$ podobnym stylu rodzina zakonów franciszkańskich w Polsce na bazie drugiego wydania włoskojęzycznej pracy zbiorowej pt. Dizionario francescano spiritualità (red. E. Caroli, Padova 1995) w 2006 roku i ponownie w 2016 roku wydała Leksykon duchowości franciszkańskiej (red. E. Kumka, Kraków-Warszawa 2016).

Można jedynie ubolewać, że w Polsce brakuje opracowywanego na bieżąco katalogu publikacji (książek i artykułów) w zakresie duchowości katolickiej, zarówno naukowych, jak i popularyzatorskich, których każdego roku ukazuje co najmniej kilkadziesiąt, nie mówiąc o prawdziwej lawinie książek oraz wydawnictw multimedialnych służących celom formacyjnym oraz ewangelizacyjnym. To wszystko potwierdza, jak ważną rolę w przestrzeni refleksji teologicznej i duszpasterstwa odgrywa teologia duchowości katolickiej.

${ }^{30}$ Zob. M. Chmielewski, Dni Duchowości, Tygodnie Duchowości, w: Encyklopedia 100-lecia KUL, red. E. Gigilewicz i in., Lublin 2018, s. 161-162. 
W dobie „powszechnej potrzeby duchowości”, o której pisze św. Jan Paweł II w liście apostolskim Novo millennio ineunte ( $\mathrm{nr} 33$ ), uznając ją za znak naszych czasów, ustrukturalizowana teologia duchowości katolickiej, mająca status pełnoprawnej dyscypliny naukowej, jest niezmiernie potrzebna. W wydanej przez Kongregację Nauki Wiary instrukcji o powołaniu teologa w Kościele Donum veritatis (z 25 V 1990) czytamy, że „Kościół nie może zrezygnować z posługi, jaką spełnia teologia, czyli nauka, którą znamionuje przeniknięte wiarą dążenie do zrozumienia wiary" (nr 1), gdyż „w każdej epoce teologia odgrywa ważną rolę w realizowaniu przez Kościół planu Boga. [...] Jednak jej znaczenie wzrasta jeszcze bardziej w czasach duchowych i kulturowych wstrząsów..." ( $\mathrm{nr}$ 2), a takimi bez wątpienia są pierwsze dziesięciolecia trzeciego millennium chrześcijaństwa.

Teologia duchowości, jako dyscyplina naukowa, zabezpiecza teologię w jej zasadniczej funkcji „zrozumienia” i „przekazywania wiary”, a jednocześnie domaga się, aby teolog pozostał wierny powołaniu „intensywnego przeżywania swej wiary” i „łączenia badań naukowych z modlitwą" (nr 8), które wymagają „duchowego wysiłku związanego ze zdobywaniem ścisłości i uświęceniem" (nr 9).

\section{BIBLIOGRAFIA}

Alvarez T., Experiencia cristiana y Teologia Espiritual, „Seminarium” 26(1974), s. 94-109.

Asti F., Spiritualità e mistica. Questioni metodologiche, Città del Vaticano 2003.

Asti F., Approcci socio-psicologici per una rinnovata teologia spirituale, „Mysterion” 5(2012), nr $1,25-44$

BAlthasar H. URS von, Spiritualità, „Theologisches Jahrbuch” 5(1961), s. 170-178.

BARTNIK Cz.S., Hermeneutyka personalistyczna, Lublin 1994.

BARTNIK Cz.S., Metodologia teologiczna, Lublin 1998.

BELDA M., Lo statuto epistemologico della teologia spirituale nei manuali recenti (1978-1989), „Annales theologici” 6(1992), s. 454-457.

Bernard Ch.A., Teologia spirituale, Milano 1987.

BERNARD Ch.A., Introduzione alla teologia spirituale, Casale Monferrato 1994.

CAvazos-GonzÁlez G., Il metodo socio-spirituale per lo studio teologico dei classici spirituali cristiani, „Mysterion” 8(2015), nr 2, s. 206-216.

Chmielewski M., Metodologiczne problemy posoborowej teologii duchowości katolickiej, Lublin 1999. 
Chmielewski M., Teologia duchowości w wybranych dokumentach Kościoła, „Roczniki Teologiczne" 47(2000), z. 5, s. 93-101.

Chmielewski M., „Biblioteka Życia Wewnętrznego”, w: Leksykon duchowości katolickiej, red. M. Chmielewski, Lublin-Kraków 2002, s. 82.

Chmielewski M., Las fuentes de la teología espiritual, w: Dar razón de la esperanza. Homenaje al prof. dr. José Luis Illanes, red. T. Trigo, Pamplona 2004, s. 843-855.

Chmielewski M., Ks. Antoni Stomkowski prekursor akademickiej teologii duchowości w Polsce (1957-2007), w: Lectio divina (Homo meditans, t. 29), red. J.M. Popławski, Lublin 2008, s. 161-179.

ChMielewski M., Duchowość chrześcijańska na tle współczesnych koncepcji duchowości. Zarys problematyki, „Roczniki Teologiczne” 64(2017), z. 5, s. 159-179.

Chmielewski M., Współczesna polska teologia duchowości, „Duchowość w Polsce” 19-20(20172018), s. 191-217.

Chmielewski M., Instytut Teologii Duchowości, w: 100 lat teologii na KUL, red. S. Nowosad, J. Mastej, Lublin 2018, s. 109-115.

Chmielewski M., Dni Duchowości, Tygodnie Duchowości, w: Encyklopedia 100-lecia KUL, red. E. Gigilewicz i in., Lublin 2018, s. 161-162.

Colosio I., Tentativo di una nuova definizione della teologia spirituale, „Rivista di Ascetica e Mistica" 21(1976), s. 298-301.

Eulogio de la Virgen del Carmel, Proceso histórico de la formación de la teología espiritual como ciencia, „Teología Espiritual” 4(1960), s. 483-485.

Garcia C., Corrientes nuevas de teología espiritual, Madrid 1971.

GARCiA C., Evolución del método de teología espiritual en las últimas décadas, „Mysterion” 12(2019), nr 1, s. 15-26.

Garcia J.-M., Teología espiritual. Elementos para una definición de su estatuto epistemologico, Roma 1995.

GARcía J.-M., Lo statuto epistemologico della Teologia spirituale in contesto interdisciplinare, „Mysterion” 5(2012), nr 2, s. 48-75.

GARCíA GutiérRez J.M., Il metodo «teologico esperienziale» della teologia spirituale, „Mysterion" 9(2016), nr 1, s. 5-17.

Gogola J.W., Metoda empatyczno-sapiencjalna w teologii duchowości, „Itinera spiritualia” 1(2008), s. 21-34.

GRILlo A., Il dono e la mistica: una svolta „teologica” della fenomenologia?, w: Esperienza mistica e pensiero filosofico. Atti del Colloquio „Filosofia e mistica”, red. F. Miano, G. de Simone, Città del Vaticano 2003, s. 26-43.

GuERra A., Teología espiritual una ciencia no identificada. „Revista de Espiritualidad” 39 (1980), s. 335-414.

Huerga A., La encíclica de León XIII sobre el Espíritu Santo, „Teología Espiritual” 26(1982), s. $72-83$.

LASIĆ D., Theologia christiana perfectidica, „Antonianum” 42(1967), s. 188-258.

MARIAŃSKi J., Nowa duchowość jako megatrend społeczno-kulturowy - mit czy rzeczywistość, „Uniwersyteckie Czasopismo Socjologiczne” 2015, nr 13, s. 22-45. 
Moioli G., Dimensione esperienziale della spiritualità, w: Spiritualità. Fisionomia e compiti, red. B. Calati, B. Secondin, T.P. Zecca, Roma 1981, s. 45-62.

MAtANic A.G., La spiritualità come scienza. Introduzione metodologica allo studio della vita spirituale cristiana, Cinisello Balsamo 1990.

Nowak A.J., Postuszeństwo Kościołowi świętemu fundamentem formacji kapłańskiej w świetle Jana Pawta II posynodalnej adhortacji apostolskiej „Pastores dabo vobis”, „Roczniki Teologiczne" 42(1995), z. 5, s. 39-59.

Pereira de Oliveira L., Fenomenologia della Religione e Teologia Spirituale. Applicazione del Metodo di Juan de Dios Martin Velasco alla Teologia Spirituale, „Mysterion” 10(2017), nr 1, s. 36-43.

PERRIN D.B., Metodologia ermeneutica nella spiritualità cristiana: fenomenologia e interdisciplinarità, ,Mysterion” 10(2017), nr 1, s. 5-21.

Queralt A., La «Espiritualidad» como disciplina teológica, „Gregorianum” 60(1979), s. 321-375.

SŁomka W., Doświadczenie chrześcijańskie i jego rola w poznaniu Boga. Studium w świetle fenomenologicznej metody Husserla, Lublin 1972; przedruk w: Bóg jest Miłościa. Księga jubileuszowa ku czci Księdza Profesora Waleriana Słomki z okazji pięćdziesięciolecia święceń kapłańskich, red. M. Chmielewski, A. Rybicki, Lublin 2006, s. 65-220.

Soto GonZALes M., Sobre la antropologia hermeneutica como metodo, „Estudios”36(1980), s. 5-11.

THILS G., Saintetè chrètienne, Thielt 1958.

ZAS FRIZ DE COL R., La teologia spirituale e la ricerca della triplice unità: disciplinare, intradisciplinare e interdisciplinare, „Mysterion” 6(2013), nr 1, s. 65-85.

ZAS FRIZ DE COL R., Un metodo fenomenico-cognitivo per comprendere la vita cristiana e il suo sviluppo, „Mysterion” 6(2013), nr 2, s. 191-219.

ZAS FRIZ DE COL R., Dall'ascetica e mistica alla vita cristiana. Novant'anni dopo, „Mysterion” 12(2019), nr 1, s. 27-42.

\section{TEOLOGIA DUCHOWOSCI JAKO DYSCYPLINA NAUKOWA ZARYS PROBLEMATYKI}

\section{STRESZCZENIE}

Wśród specjalności oferowanych przez wydziały teologiczne na uniwersytetach i uczelniach często znajduje się teologia duchowości. Oznacza to, że jest to pełnoprawna dyscyplina naukowa. Ma ona swoją historię, własną nazwę, która ją identyfikuje, przedmiot badań, konkretne źródła i odpowiednią metodę badawczą. Na poziomie uniwersyteckim teologią duchowości zajmuje się wielu naukowców, których osiągnięcia są uznawane i doceniane w świecie nauki. Oprócz struktur uniwersyteckich, w których prowadzone są badania i dydaktyka oraz zwoływane konferencje, teologowie duchowości tworzą organizacje i stowarzyszenia posiadające osobowość prawną.

Artykuł ma na celu pogłębienie wyżej wymienionych zagadnień, biorąc pod uwagę polskie środowisko teologiczne i kościelne.

Znajomość głównych kwestii metodologicznych jest bardzo ważna dla każdego zaangażowanego teologa, rzetelnej pracy naukowej, a także jego powołania w Kościele.

Słowa kluczowe: duchowość; teologia; metodologia; nauka; metoda teologiczna; polskie środowisko teologiczne. 